\title{
Socio-Economic Relevance of Cassava to Rural Peasant Farmers in the Awutu-Effutu-Senya and Atebubu-Amantin Districts of Ghana
}

\author{
Paul Kofi Andoh \\ Department of Sociology \\ University of Ghana, Legon \\ E-mail: Furnstyle2@yahoo.com
}

\begin{abstract}
This paper examines the socio-economic relevance of cassava to rural peasant farmers in two districts in Ghana, with the aim of highlighting its significance in ensuring improvement in rural socio-economic livelihoods. The study employed mainly the quantitative research technique in collecting data from 120 respondents from six farming communities in the Awutu-Effutu-Senya and Atebubu-Amantin districts of the Central and Brong Ahafo regions of Ghana respectfully. Data collected with structured questionnaire were analyzed in accordance with the study objective. The paper establishes that since its introduction to Ghana in the sixteenth century, cassava has contributed and continues to contribute significantly to the socio-economic livelihoods of peasant farm producers in the two districts. It is a major crop cultivated in combination with other crops and hence a major contributor to the income of peasant farmers. It also serves as a major source of occupation of rural dwellers and hence provides them with a sense of relevance and dignity in their communities. To this extent, the paper suggests among others that the state pays more attention to research and development with the view to introducing a higher yielding cassava variety that would be suitable for Ghanaian soil type, and to facilitate the development of an integrated cassava industry in Ghana to link peasant farm producers to the growing global market for cassava-starch and its derivatives.
\end{abstract}

KEY DESCRIPTORS: Rural Peasant Farmers, Socio-economic Livelihood, Peasant Economy, Depeasantization of Agriculture, Rural Transformation.

\section{INTRODUCTION}

Cassava is a perennial woody plant with an edible root. The word cassava comes from "casabi", the name given by the Arawak Indians to the root. It is known as "yuca" in Spanish, "manioc" in French, "mandioc" in Portuguese; "cassave" in Dutch, and "maniok" in German. Cassava (Manihot utilissima) was widely cultivated as a staple crop in pre-Columbian tropical America. It is said to originate from Brazil from where it was introduced to other parts of the Caribbean by Portuguese traders (Jones, 1959). The Portuguese later introduced the crop to Africa in the $16^{\text {th }}$ century. Since then cassava has been cultivated in most tropical countries situated in the equatorial belt, between $30^{\circ}$ north and $30^{\circ}$ south of the equator, attesting to the fact that it is adaptable to a wide range of ecosystems. 
Research shows that cassava has high efficiency in producing carbohydrate. It is tolerant to drought and to impoverished soils, even though it also thrives on fertile, sandy-clay soils. It is highly flexible with respect to the timing of planting and harvesting and hence plays an essential role for food security, especially in regions which are prone to drought and with poor soils. Statistics indicate that it is the world's fourth most important staple crop, coming only after rice, wheat and maize and is an important component in the diet of over one billion people (FAO and IFAD, 2000). This paper examines the socio-economic importance of cassava to rural peasant farmers, by systematically presenting the problem under investigation and study objectives, the research method employed, some theoretical perspectives from relevant literature, the presentation analysis of primary data, conclusion and recommendations.

\section{THE PROBLEM STATEMENT AND STUDY OBJECTIVE}

While cassava has been produced in Ghana since the sixteenth century and has attracted recognition by various governments as an important root crop since the early 1890s, there seem to be lack of concerted and sustained effort to promote its cultivation not only for consumption at the local level, but also for industrial use and export. A review of the performance of the food crops sub-sector reveals the significant contribution of cassava to food security in Ghana. Compared with other root crops (yam, cocoyam, and plantain), cassava's contribution to the root crops sub-sector averaged about 54 percent between 2000 and 2005 . Between the same period, the average contribution of yam, cocoyam, and plantain were about 22 percent, 10 percent, and 14 percent respectively (ISSER, 2006).

Alderman and Higgens (1992) note that the importance of cassava in Ghana is confirmed in terms of crop area cultivated, total production, contribution to Agricultural Gross Domestic Product (AGDP) and food expenditure shares. Thus, in a survey report, which was sponsored by the International Fund for Agricultural Development (IFAD), the Ministry of Food and Agriculture (undated) observed that the average area planted to cassava, which was about 387 000 ha in 1986, increased to 590000 ha in 1996 nationwide. During the same periods, cassava production also increased from about 2.9 million tonnes to 7.11 million tonnes. Thus far, cassava has been perceived as the largest agricultural commodity produced in Ghana and represents 22 percent of Agricultural Gross Domestic Product (AGDP) compared to 5 percent for maize, 2 percent for rice, sorghum and millet, 14 percent for cocoa, 11 percent for forestry, 7 percent for fisheries and 5 percent for livestock (Al-Hassan, 1989; Dapaah, 1996).

The attempt in 2001 to promote the cultivation of cassava for the production of starch mainly for export with the launch of the Presidential Special Initiative (PSI) on cassava-starch, has been saddled with problems, making the anticipated cassava-starch industry in Ghana a mirage (Andoh, 2007; Tonah, 2006). At the dawn of the new millennium, Ghana's development was deemed to be heavily dependent on the growth of its agriculture because of its contribution to income, employment generation and economic output (ISSER, 2006). Under Ghana's Root and Tuber Improvement Program, new varieties of cassava and sweet potatoes were developed and multiplication farms established to provide planting materials to farmers across the country in 
2005. Yet, the sector is still plagued with technological bottlenecks as well as policy ineptitude on the part of governments. While some effort at modernizing agriculture and encouraging agro-based industries are encapsulated in Ghana's Growth and Poverty Reduction Strategy (GPRS II) for 2006-2009, much emphasis has not been on root crop like cassava, but on other high-value cash and stable crops such as mangoes, pineapple, cashew and vegetables under its Trade and Investment Programme for a Competitive Export Economy (TIPCEE) and the US Millennium Challenge Account - MCA (ISSER, 2006). Even in this situation, cassava is still cultivated by many farmers in rural Ghana because of its significance in sustaining rural livelihoods. The lack of appreciation of the important role cassava plays in rural livelihoods seems to relegate the crop to the background as far as national development efforts are concerned.

Consequently, the primary objective of this paper is to highlight the socio-economic importance of cassava to rural peasant farmers in two districts in Ghana in relation to source of employment, income, and ability to meet the education and health needs of their households. By highlighting the socio-economic importance of cassava to peasant farm producers, the study hopes to draw attention of policy makers to the fact that cassava could possibly become Ghana's 'white gold' because of the inherent possibility for income generation for the farmers and the nation at large through processing for starch and its derivatives for industrial use locally and internationally.

\section{THE RESEARCH METHOD}

The study was conducted in the Awutu-Effutu-Senya and Atebubu-Amantin districts of the Central and Brong Ahafo regions of Ghana respectively. These were purposively selected because they are key cassava producing districts in Ghana and consequently became sites for the PSI on Cassava. Consequently, a modern cassava processing factories were established to process cassava into industrial starch for export. The Atebubu-Amantin District hosts cassavaflour processing centers while preparing to host a modern cassava processing factory, at the time of this study.

In each district, three communities were purposively selected, bringing the total number of communities to six. The selection criteria were the existence of Farmer-Based Organizations (FBOs), proximity to cassava-processing plant, and accessibility. Primary data for the study were derived from administration of two sets of structured questionnaires, which were administered to 120 respondents who were randomly selected among peasant farmers from all the six selected communities. Table 1 below captures the selected districts, communities, membership of FBO and the sample size selected.

Table 1: Selected Districts, Communities, FBO Membership and Selected Sample

\begin{tabular}{|l|l|l|c|c|}
\hline Region & District & $\begin{array}{c}\text { Selected } \\
\text { Communities }\end{array}$ & $\begin{array}{c}\text { FBO } \\
\text { Membership }\end{array}$ & $\begin{array}{c}\text { Sample } \\
\text { Selected }\end{array}$ \\
\hline & & Penim & 120 & 20 \\
\hline
\end{tabular}




\begin{tabular}{|l|l|l|c|c|}
\hline Central & $\begin{array}{l}\text { Awutu-Effutu- } \\
\text { Senya }\end{array}$ & Fianko & 85 & 20 \\
\cline { 3 - 5 } & & Ofaada & 110 & 20 \\
\hline \multirow{4}{*}{ Brong Ahafo } & $\begin{array}{l}\text { Atebubu- } \\
\text { Amantin }\end{array}$ & Atebubu & 300 & 20 \\
\cline { 3 - 5 } & Amantin & 175 & 20 \\
\cline { 3 - 5 } & Watro & 105 & 20 \\
\hline \multicolumn{2}{|l}{ Total } & $\mathbf{8 9 5}$ & $\mathbf{1 2 0}$ \\
\hline
\end{tabular}

Source: Field Work, 2006

The sample size of 120 is 13.4 percent of the target population. This was chosen on the basis of availability of time, financial constraints and target population. The target population was expected to be fairly homogeneous in terms of their social and economic characteristics. The membership lists of the FBOs in each selected community were used as sampling frame. In each of the six selected communities, 20 respondents were chosen for this study. This was also done to ensure equal representation of respondents from the six selected communities. The raw data gathered were edited, coded and organized into frequency tables using the Statistical Package for the Social Sciences (SPSS) software, before analyzing them.

\section{RURAL TRANSORMATION IN GHANA}

Since Ghana attained independence in 1957, various attempts have been made at rural development by various governments. However, the evidence available shows that not much has been achieved in terms of transforming social and economic formations in rural Ghana. The rural population is still involved in small scale peasant economy, characterized by primitive or outmoded technology, low productivity, low income, post harvest losses, and unreliable price mechanisms. In view of the fact that the rural peasant farm population is larger than the urban population, it behoves on policy makers to realize that the eventual economic take-off of the economy of Ghana will, to a large extent, depend on a well planned and systematic depeasanization of agriculture (Asamoa, 2001). Referring to rural farm producers in Ghana, Haizel (1994:22) notes that, "by their numbers alone ... they have a legitimate claim to our attention. Rather than disregarding them as a drag, we must make them the basis of all our agricultural development effort in Africa. If bigness is the order of the day, then we must organize them for it".

In finding a niche in the global economy, Ghana's endowment based competitive advantage lies in agriculture, including traditional and non-traditional crops. Even though most Ghanaians are involved in agriculture, their activities are mostly subsistence based on small holder farming. Moreover, 80 percent of poverty in Ghana is estimated to be in the rural areas and concentrated among subsistence farmers (Government of Ghana, 2003). No serious national development effort can ignore rural development as an essential component. Among the many state initiative aimed at improving the socio-economic livelihood of rural farm producers, especially those producing fresh cassava, is the PSI on Cassava-Starch, which was introduced in 2001 and aimed at developing an integrated cassava-starch industry in Ghana with peasant farmers as key actors. In an earlier study (Andoh, 2007), it was found that the PSI on cassava- 
starch had the potential of improving the incomes of peasant farm producers in the study areas. It was however noted that this could only happen if stakeholders in the envisioned cassava-starch industry were properly enmeshed into the industry through sound management of the initiative and collaboration with local people.

Asamoa's (2001) study on Depeasantization of Africa's Rural Economy: The Ghanaian Experience, suggests that the peasant economy of Ghana since colonial times has largely remained intact, with the use of cutlass and hoe as major farm implements. Agricultural production has largely remained subsistent with farm labour provided mainly by family members. Thus, in the view of Tonah (2006), peasant farming has become synonymous with traditionalism, unwillingness to change, inefficiency and a general backward form of land use and production. Modern services like roads, electricity, water and health are woefully undersupplied and rural folks in Ghana still cry for these facilities. For instance, in four out of the six communities involved in this study, there is no electricity, no health centre and no pipe borne water. Educational facilities leave much to be desired in rural Ghana. In recent times, there have been attempts to improve on these but more needs to be done in order to ensure improvement in the quality of life of the rural population. Even though there is no sign of starvation, the general quality of life of many rural populations can best be described as challenging due to unfair markets and resource deprivations. Against this background, there is a call for grassroots mobilization of resources towards industrialization but this should be based on "a well conceived industrialization programme, which could dovetail excellently into development and demands in the agricultural sector and vice-versa" (Asamoa, 2001:83).

\section{THE CULTIVATION OF CASSAVA AMONG PEASANT FARMERS IN GHANA}

Cassava is cultivated by many peasant farmers in various parts of Ghana. It was introduced to Ghana in the sixteen century by the Portuguese and later indigenous Ghanaian farmers took up its cultivation, perhaps due to its adaptability to the Ghanaian environment. Even though cassava was introduced into the country in the sixteenth century and became a major crop in farming systems of Ghana, it remained in obscurity and neglected perhaps until the 1990's when its importance as a main source of carbohydrates and regular source of income to rural dwellers, as well as contribution to Agricultural Gross Domestic Product (AGDP) became of interest. However, since 1990s, the Governments of Ghana, through the Ministry of Food and Agriculture (MoFA), have demonstrated determination and commitment to promote cassava cultivation for the alleviation of poverty particularly in rural households and communities (MoFA, n.d.).

According to Adams (1957), the Portuguese grew cassava around their trading ports, forts, and castles as a major food source for them and their slaves. He further notes that by the second half of the $18^{\text {th }}$ century, cassava had become the most widely grown and used crop of the people of the coastal plains. Consequently, the Akan name for the crop, 'bankye,' is said to be a contraction of Akan words, 'Aban Kye,' meaning a gift from the government (castle). 
Korang-Amoako, Cudjoe and Adams (1987) observed that the spread of cassava from the coast into the hinterland was very slow. It reached Ashanti (and Brong Ahafo) and the northern regions of Ghana in the early 1930s. Moreover, up until the 1980s, the Akans of the forest belt preferred the cultivation of plantain and cocoyams to cassava. In the northern region, some farmers preferred sorghum and millet to cassava. Cassava became firmly established in many areas after the serious drought of 1982/83 when all other crops failed completely. Since then, cassava and its various local preparations including fufu, gari and konkonte became very popular food sources throughout Ghana and not only in the coastal regions, as was the case some 20 years before (MoFA, n.d.).

Reviewing the Ghana Living Standard Survey (GLSS) reports of $1987 / 88$ and 1988/89, the MoFA (undated) further observed that 83 percent of the sampled households were engaged in cassava production in $1987 / 88$. By $1988 / 89$, the GLSS recorded a one percent decline in the number of sampled households engaged in cassava production, with a corresponding one percent increase in maize producing households. The presentation of data from the 1991/92 GLSS III survey differed slightly from the report of the earlier surveys so it is not possible to track the trends in numbers of households engaged in the production of cassava and maize. What the reports appeared to demonstrate was a declining percentage of households cultivating cassava by the early 1990s, albeit small, relative to those growing maize. Consequently, there have been efforts on the part of governments to promote cassava production since the 1990s.

Following the launch in 1988 of the National Root and Tuber Crops Improvement Project (NTRCIP), three improved cassava varieties were released to farmers in 1993. This effort was complemented by the implementation of various activities on cassava under the National Agricultural Research Project (NARP) including; crop improvement, agronomy, integrated pest management, post-harvest management, processing and socio-economic studies by several research institutions and universities. Government policies thereafter have contributed to increasing the importance of cassava in Ghana. The establishment of an export led industry in cassava chips for export and for the local livestock industry by a private company, Transport and Commodity General, also increased interest in the crop in many parts of Ghana.

The MoFA (Undated) reports a positive impact of cassava on equity (including gender) with women mainly responsible for processing and marketing and with environmental benefits. It is evident that with support for the development of improved varieties for the varied agroecological zones, the supply of planting materials, support for research and extension, innovations in methods of harvesting, promotion of processing into various forms such as chips, pellets, starches, flours and for industrial applications and, the elimination of constraints to market development, output of cassava could expand drastically. This would accord cassava the recognition of contributing adequately to the economy of Ghana through food security, poverty alleviation and application for several uses. It is in the same light that the PSI on Cassava-Starch was launched in 2001 by the then Government of Ghana to transform cassava from a staple food crop into an industrial crop for processing into starch mainly for export. 
CASSAVA PRODUCTION TRENDS, AREA UNDER CULTIVATION AND YIELD PER HECTARE (1990 2005)

In Ghana, cassava production in the 1990's witnessed consistent growth. The growth trend continued from 2001 until 2004 when production began to decline (ISSER, 1994; 1997; 2000; 2005). Even with the decline, the production level had been higher than was experienced in the 1990s. Table 2 (column 2) shows cassava production trends in Ghana from 1990 to 2005.

Table 2: Cassava Production Trends, Area Under Cultivation, and Yield Per Hectare in Ghana From 1990 to 2005

\begin{tabular}{|c|c|c|c|}
\hline Year & $\begin{array}{c}\text { Output } \\
\text { (in ‘000 tonnes) }\end{array}$ & $\begin{array}{c}\text { Area Under } \\
\text { Cultivation } \\
\text { (in ‘000 hectares }\end{array}$ & $\begin{array}{c}\text { Yield Per Hectare } \\
\text { (in tonnes) }\end{array}$ \\
\hline 1990 & 2,712 & 323 & 8.4 \\
\hline 1991 & 5,701 & 535 & 10.7 \\
\hline 1992 & 5,662 & 552 & 10.3 \\
\hline 1993 & 5,973 & 532 & 11.2 \\
\hline 1994 & 6,025 & 520 & 11.6 \\
\hline 1995 & 6,612 & 551 & 12.0 \\
\hline 1996 & 7,111 & 591 & 12.0 \\
\hline 1997 & 7,150 & 593 & 12.1 \\
\hline 1998 & 7,172 & 630 & 11.4 \\
\hline 1999 & 7,845 & 640 & 12.3 \\
\hline $\mathbf{2 0 0 0}$ & 8,107 & 660 & 12.3 \\
\hline $\mathbf{2 0 0 1}$ & 8,966 & 726 & 12.3 \\
\hline $\mathbf{2 0 0 2}$ & 9,731 & 794 & 12.3 \\
\hline $\mathbf{2 0 0 3}$ & 10,239 & 807 & 12.7 \\
\hline $\mathbf{2 0 0 4}$ & 9,738 & 783 & 12.4 \\
\hline $\mathbf{2 0 0 5}$ & 7,791 & 750 & 10.4 \\
\hline
\end{tabular}

Source: Compiled from The State of the Ghanaian Economy in 1994, 1997, 2000 and 2005. By Institute of Statistics, Social and Economic Research - ISSER

The data on area under cassava cultivation show that between 1990 and 2000, there was a little over 100 percent increase in area cultivated (see ISSER, 1994, 1997, 2000, 2005). The growth trend continued rapidly from 2001 until 2004 when decline set in. Even though there has been a decline, the area under cultivation is still higher than the 1990's figures. Table 2 (column 3) shows the trend in area under cassava cultivation in Ghana from 1990 to 2005.

An analysis of cassava yield per hectare in Ghana since 1990 (Refer to Table 2, column 4) shows that, Ghana has done better than the average for Africa - 8.2 metric tonnes per hectare between 1993 and 1995, and Latin America and the Caribbean - 11.9 metric tonnes per hectare 
between 1993 and 1995 (see Andoh,2007:72). Apart from 1990, Ghana's cassava yield per hectare has been above 10 tonnes. The yield per hectare between 1999 and 2004 was above 12 tonnes. Even though Ghana's yield appears higher than the average of Africa and Latin America and the Caribbean, it is still below that of Thailand's over 20 tonnes. Indeed, Thailand is the leading exporter of cassava-starch in the world and has a well developed cassava-starch industry. Ghana could therefore learn from the experience of Thailand in its attempt to develop an integrated cassava-starch industry.

\section{SOCIO-ECONOMIC IMPORTANCE OF CASSAVA TO PEASANT FARMERS}

The main occupation of rural populations is their means of subsistence. In many rural communities in Ghana, subsistent farming (i.e. crop cultivation) is a basic engagement. The importance of cultivation cannot be over-emphasized because it sets the tone for human development. "One of the greatest things that ever happened in the history of mankind (sic) was when man (sic) first learnt to cultivate. This event was significant because wherever it occurred, it set the base for greater human development" (Haizel, 1994:9). Table 3 below shows the main occupations of the respondents from the two districts.

Table 3: Respondents' Main Occupation

\begin{tabular}{|l|c|c|c|c|c|c|}
\hline \multirow{2}{*}{ Main Occupations } & \multicolumn{2}{|c|}{$\begin{array}{c}\text { Awutu-Effutu- } \\
\text { Senya District }\end{array}$} & \multicolumn{2}{c|}{$\begin{array}{c}\text { Atebubu-Amantin } \\
\text { District }\end{array}$} & \multicolumn{2}{|c|}{ Total } \\
\hline & Freq & \%age & Freq & \%age & Freq & \%age \\
\hline Farming (cultivation) & 57 & 95.0 & 49 & 81.6 & 106 & $\mathbf{8 8 . 4}$ \\
\hline Trading & 1 & 1.7 & 5 & 8.3 & 6 & $\mathbf{5 . 0}$ \\
\hline Formal Employment & 2 & 3.3 & 4 & 6.7 & 6 & $\mathbf{5 . 0}$ \\
\hline Craft & 0 & 0.0 & 1 & 1.7 & 1 & $\mathbf{0 . 8}$ \\
\hline Cassava Processing & 0 & 0.0 & 1 & 1.7 & 1 & $\mathbf{0 . 8}$ \\
\hline Total & $\mathbf{6 0}$ & $\mathbf{1 0 0 . 0}$ & $\mathbf{6 0}$ & $\mathbf{1 0 0 . 0}$ & $\mathbf{1 2 0}$ & $\mathbf{1 0 0 . 0}$ \\
\hline
\end{tabular}

Source: Author's Field Work, 2006

As expected in a rural community, 88.4 percent of the respondents from the two districts had farming (cultivation) as their main occupation, compared to 5.0 percent who had trading as their main occupation and another 5.0 percent who had formal employment as their main occupation. One (1) respondent had craft and another one (1) had cassava processing as their main occupation. The data however show that the Atebubu-Amantin District had fewer respondents (81.6\%) with farming as their occupation compared to that of the Awutu-EffutuSenya District (95.0\%). Only one (1) respondent in the Awutu-Effutu-Senya District had trading as a main occupation as against Atebubu-Amantin District's six (6). Also, two (2) respondents from the Awutu-Effutu-Senya District had formal employment against six (6) for the AtebubuAmantin District. This difference may be attributable to the fact that apart from Watro, which is a typical village, the two other communities selected for this study in the Atebubu-Amantin District (Atebubu and Amantin) are the two major towns in the District and therefore trading activities there are quite brisk. Moreover, Atebubu has a Teacher Training College and Amantin 
has a Senior Secondary School in addition to basic schools with many teachers residing in the communities. These teachers also engage in farming as a secondary occupation. However, all the communities selected in the Awutu-Effutu-Senya District are typical villages where there is no electricity, no Senior High School and no market place. Even though there are basic schools, most of the teachers do not reside in the communities, mainly because of the lack of social amenities. They live in Bawjiase, the nearest town, from where they commute to work.

\section{Main Sources of Income}

Given the fact that the respondents in both Awutu-Effutu-Senya and the Atebubu-Amantin districts survive mainly on farming activities, their main sources of income also reflect their economic activities. Generally, farming (cultivation) constitutes their main source of income, followed by cassava processing, animal husbandry, trading, craft, formal employment and others (including bee keeping, remittance, fishing, farm labourer etc.). Table 4 below depicts the respondents' main sources of income.

Table 4: Main Sources of Income ( $N=120)$

\begin{tabular}{|lccccccc|}
\hline \multirow{2}{*}{$\begin{array}{l}\text { Sources of Income } \\
\text { Farming (cultivation) }\end{array}$} & \multicolumn{2}{c}{$\begin{array}{c}\text { Awutu-Effutu- } \\
\text { Senya District }\end{array}$} & \multicolumn{2}{c|}{$\begin{array}{c}\text { Atebubu-Amantin } \\
\text { District }\end{array}$} & \multicolumn{2}{c|}{ Total } \\
\cline { 2 - 9 } & Freq & \%age & Freq & \%age & Freq & \%age \\
\hline Cassava Processing & 60 & 100.0 & 60 & 100.0 & 120 & $\mathbf{1 0 0 . 0}$ \\
\hline Trading & 25 & 41.7 & 13 & 1.7 & 38 & $\mathbf{3 1 . 7}$ \\
\hline Animal Husbandry & 10 & 16.7 & 10 & 16.7 & 20 & $\mathbf{1 6 . 7}$ \\
\hline Craft & 6 & 10.0 & 16 & 26.7 & 22 & $\mathbf{1 8 . 3}$ \\
\hline Formal Employment & 3 & 5.0 & 9 & 15.0 & 12 & $\mathbf{1 0 . 0}$ \\
\hline Others & 4 & 6.7 & 4 & 6.7 & 8 & $\mathbf{6 . 7}$ \\
\hline Source: Author & 2 & 1.7 & 3 & 2.5 & 5 & $\mathbf{4 . 2}$ \\
\hline
\end{tabular}

Source: Author's Field Work, 2006

Even though the respondents have multiple sources of income, the source of income that is common to all of them is farming (cultivation). Schubert (1994) and Ayanwale, Bamire and Alimi (2006) observe that the main source of income for rural populations is agriculture and since majority are small holder family operators, poverty is prevalent among them. Against this background and the fact that rural populations constitute the greater proportion of the population of Ghana, if any meaningful development of the country as a whole is to be realized, there is the need to transform peasant agricultural practices into more rewarding productive activities by creating channels and opportunities for marketing their produce competitively. In Ghana, traditional farmers constitute not less than 60 percent of working population and account for about 90 percent of local food supply (Haizel, 1994).

\section{Cassava as a Major Income Producing Crop}


As has been noted in the preceding section, cassava is a perennial woody plant with an edible root. It is the base of many products. It is used commercially for the production of animal feed and starch-based products worldwide. It is an important root crop in the farming systems of tropical Africa and in Ghana. It is also a major part of the diets of the people and a main source of livelihood. Its root can be eaten raw, boiled before consumption, or processed into a variety of granules, pastes and flours. The stem is cut and preserved for future use and the leaves are consumed as green vegetable in soups and stews throughout tropical Africa (Tonah, 2006). All farmers interviewed in this research cultivate the crop in combination with other crops.

However, cassava cultivation featured prominently in their farming activities.

It was noted during the field interaction with the farmers in the two districts that their lands are conducive for the cultivation of cassava. The people have been cultivating the crop for several centuries, perhaps since its introduction into the country. One young man at one of the villages in the Awutu-Effutu-Senya District explained that cassava cultivation was the main work of their forefathers and the present generation was only continuing from where forefathers had left off. Also, in Atebubu, a man said that even when a cassava stick was planted on a nearby school's bare football pitch, it would grow well. It is therefore not surprising that all the 120 respondents included in this study cultivated cassava.

Even though all the respondents cultivated cassava along with other crops, cassava was the main crop for 93.3 percent of the respondents from the Awutu-Effutu-Senya District and for 35.0 percent from the Atebubu-Amantin District. For farmers in all the six communities included in this study, cassava is of major economic significance since the bulk of their farm income is derived from cultivating cassava. In the Awutu-Effutu-Senya District, cassava is mainly consumed, processed into cassava dough or 'gari' (roasted cassava granules) and sold on the open market. However, in the Atebubu-Amantin District, the people consume less cassava because of the abundance of yam and maize in the area. They sell the fresh cassava tubers on the open market or dry the tubers after peeling and then pack into sacks for sale on the open market. It is very common to find heaps of dry cassava packed in sacks for sale at markets in the district. The dry cassava is milled into powder and used to prepare a local food called 'kokonte' which is eaten across the country. Table 5 shows that among all the crops cultivated in the two districts, cassava is the most important crop for majority of the respondents from both districts.

Table 5: Main Crops Cultivated by Respondents

\begin{tabular}{|c|c|c|c|c|c|c|}
\hline \multirow[t]{2}{*}{ Main Crop Cultivated } & \multicolumn{2}{|c|}{$\begin{array}{l}\text { Awutu-Effutu- } \\
\text { Senya District }\end{array}$} & \multicolumn{2}{|c|}{$\begin{array}{c}\text { Atebubu-Amantin } \\
\text { District }\end{array}$} & \multicolumn{2}{|c|}{ Total } \\
\hline & Freq & \%age & Freq & \%age & Freq & \%age \\
\hline Cassava & 56 & 93.3 & 21 & 35.0 & 77 & 64.2 \\
\hline Yam & 1 & 1.7 & 18 & 30.0 & 19 & 15.8 \\
\hline Maize & 1 & 1.7 & 15 & 25.0 & 16 & 13.3 \\
\hline Vegetables & 1 & 1.7 & 2 & 3.3 & 3 & 2.5 \\
\hline Others & 1 & 1.7 & 4 & 6.7 & 5 & 4.2 \\
\hline Total & 60 & 100.0 & 60 & 100.0 & 120 & 100.0 \\
\hline
\end{tabular}


Source: Author's Field Work

Clearly, cassava is of much importance to more farmers (56 out of 60) in the Awutu-EffutuSenya District than those of the Atebubu-Amantin District. This must have been one of the reasons why the first cassava-starch processing plant under the PSI on cassava-starch was established in the Awutu-Effutu-Senya District. It is very common to see heaps of sacks of cassava dough and roasted cassava granules when driving through communities in the District. Another common scene is the many diesel powered cassava grinding machines in almost all villages in the area. Some of these equipments are located in-between villages.

Given the fact that the main source of income for the people in the two districts is farming cultivation (see Table 2 above), with cassava as the most important crop, it becomes a major contributor to household incomes in the two districts. It is in this light that any attempt to improve cassava cultivation, processing and marketing opportunities is viewed as a welcome intervention by the people and hence their readiness to embrace it.

It is important to indicate that the price of cassava and its processed forms fluctuate widely and farmers have had to contend with these fluctuations over the years. Because fresh cassava has a very short life span (about one week from harvest) it has to be used or sold within a few days after harvest. This means that during times of bumper harvest, the glut in the market results in low prices and even where the fresh cassava is processed into dough or 'gari' (roasted granules), or 'kokonte' (dried fermented slices or flour), their prices remain low during such periods. It is only during periods of shortage where the crop is not matured for harvest or where there is drought that prices are high. The price fluctuations of raw or processed cassava means that farmers are not guaranteed sustained income from its cultivation. Perhaps one of the factors that have sustained the cultivation of cassava is the fact that the crop does well even in dry seasons and can be left in the soil for as long as the farmer is ready to harvest. It serves also as security for lean seasons.

At the time of conducting this research, (January/February) there was abundant fresh cassava, cassava dough and 'gari' in the Awutu-Effutu-Senya District and their prices were very low. For instance, a $50 \mathrm{~kg}$ of cassava dough was selling for only $\mathrm{GH}$ C14.00. Prior to that, the price had declined as low as GHC 8.00. In the lean season, when harvesting is difficult due to inadequate rainfall to moisten the soil for easier harvesting, prices could rise as high as GHC30.00. This trend does not help the peasant farmers to move easily out of poverty. Hence, the need for some policy initiatives that would ensure guaranteed prices for fresh cassava and its derivatives in order to promote growth in its cultivation, processing and consumption in Ghana and elsewhere. Dei (1992) notes that rural farm households have had to contend with the vicissitudes of the weather, farm produce prices, farm inputs and services, market access and government policies, hence their responses have depended largely on their own assessment of the perceived opportunities to them. 
In the Atebubu-Amantin District, there is the promotion of cassava flour production at the village level by the World Vision International, an international Non Governmental Organization (NGO). They have provided training, equipments and market opportunities to local women in two communities in the District (Watro and Kokofu). The District is therefore well known for the production of cassava flour which is used by bakers to produce bread and other pastries. Even though this is rather on a small scale, it signifies the importance of cassava to the people in terms of income generation.

\section{CONCLUSION}

It is evident from the analyses of data above that peasant farmers' socio-economic livelihood is largely dependent on farming and that cassava has a significant place in the scheme of activities of peasant farmers. Consequently, cassava is a major source of income with which peasant farmers are able to procure other goods and services they do not provide for themselves. Thus, they have one leg in subsistence and the other in mainstream economy. It is in this light that in an earlier study, (Andoh, 2007) a call was made for efforts on the part of policy makers to coordinate the effective incorporation of cassava production into the mainstream economy. This will help reduce its continuous marginalization against the backdrop of an emerging global cassava-starch industry and market.

Being a source of employment, cassava continues to be an important source of income to rural peasant farmers even though some have secondary sources of income like trading, craft, and formal employment. However, the unstable nature of the price of cassava and its various derivatives, the lack of guaranteed markets and guaranteed prices throughout the year make the farmers lose out after working so hard to produce the crop. Hence, there is need for streamlining of cassava production activities in Ghana with policies that could help farmers to adequately plan their cultivation and to secure guaranteed market and price for their produce at all times.

\section{RECOMMENDATIONS}

Following the conclusion drawn from the analyses of data above, the study recommends the repackaging of the PSI on cassava-starch in order to reduce, if not eliminate, the problems that confront its implementation and extension to other cassava producing districts in the country. In doing this, the focus should be on making the initiative attractive to farmers and investors. This should also require the continuous and effective consultations with peasant farmers and their representatives in the planning and implementation of any intervention by the government in order to secure their commitment to and ownership of such initiatives.

In order to make cassava an industrial crop under the expected cassava-starch industry in Ghana, there is need for rapid improvement in rural road and rail networks in the cassava producing districts. This will not only ease the difficulties in carting cassava from the farms, but also attract more investments into the agricultural sector. This should be done along with the 
provision of other social amenities like electricity, water and schools. In so doing, young people and the educated will be encouraged to invest in cassava cultivation and other ventures.

To become competitive in the global market, there is the need to maintain quality standards of both fresh cassava and processed starch. This should be achieved through effective extension services that will ensure that farmers employ appropriate agronomic practices. To this end, it is important that the state invests more resources into research and development in order to find the best yielding cassava varieties that are best suited to Ghanaian soils. A higher yielding cassava variety will not only increase output per hectare but also improve incomes of peasant farmers and make Ghana a strong competitor in the growing global cassava industry.

Finally, this paper calls for efforts on the part of government, through its rural development programmes, to gradually remove the drudgery in peasant farm practices by introducing some form of mechanization or appropriate technology in the cultivation of fresh cassava in order to enhance its cultivation, processing and marketing. But this should be done in consultation with the peasant farmers.

\section{REFERENCES}

Adams, C. D. (1957). "Activities of Danish Botanists in Guinea 1738-1850." Transactions of the Historical Society of Ghana III. Part 1 (www.fao.org/docrep/009/a0154e/A0154E07)

Alderman, H. \& Higgens, P. (1992). Food and Nutrition Adequacy in Ghana. Cornell Food and Nutrition Policy Programme, Working Paper 27.

Al-Hassan, R. (1989). "Cassava in the Economy of Ghana. In: Status of Cassava research in Africa," COSCA working paper No. 3. Edited by F. I. Nweke, J. Lynam and C. Y.Prudencio, International Institute of Tropical Agriculture, Ibadan, Nigeria.

Andoh, P. K. (2007). The State and the Peasantry: A Case Study of the Presidential Special Initiative on Cassava-Starch. An M.Phil Thesis, School of Research and Graduate Studies, University of Ghana, Legon.

Asamoa, A. (2001). Depeasantization of Africa's Rural Economies: The Ghanaian Experience. Accra: Woeli Publishing Services.

Ayanwale, B. A; S. A. Bamire and T. Alimi (2006). Poverty Reduction, Gender Equality and MicroCredit Administration in Nigeria: The Case of the Farmers Development Union. Ghana Journal of Development Studies, Volume 3, No. 1: 1-15

Dapaah, S.K. (1996). The Way Forward for Accelerated Agricultural Growth and Development. A paper presented to the Government of Ghana on behalf of the Ministry of Food and Agriculture. 
Dei, G. J. S. (1992). The Renewal of a Ghanaian Rural Economy. In Canadian Journal of African Studies. Vol. 26, No. 1. Pp 24 - 53. Canadian Association of African Studies. (http://www.jstor.org) - Retrieved on March 28, 2007

FAO/IFAD (2000). The World Cassava Economy: Facts, trends and outlook. Rome: FAO/IFAD

Government of Ghana (2003). National Medium Term Private Sector Development

Strategy, 2004-2008. Volume 1, December 2003.

Haizel, K. A. (1994). Agricultural Fundamentalism and the Capacity for Food

Production in Africa. (An Inaugural Lecture Delivered at the University of Cape Coast on March 9, 1987). Accra: Ghana Universities Press.

Institute of Statistical, Social and Economic Research (1995). The State of the Ghanaian Economy in 1994. Legon; ISSER.

(1998). The State of the Ghanaian Economy in 1997. Legon; ISSER.

(2001). The State of the Ghanaian Economy in 2000. Legon; ISSER.

(2006). The State of the Ghanaian Economy in 2005. Legon; ISSER.

Jones, W.O. (1959) Manioc in Africa. Stanford, California, USA: Stanford University Food Research Institute.

Korang-Amoakoh, S., Cudjoe, R.A. \& Adams, E. (1987) Biological control of cassava pests in Ghana. Prospects for the integration of other strategies. In Hahn, N.S.K. and F.E. Caveness (eds). Integrated pest management for tropical root and tuber crops, Ibadan, Nigeria: IITA, pp 164169

Ministry of Food and Agriculture (undated) Cassava Development in Ghana: A Country Case Study. A Country Paper Prepared for IFAD.

PSI on Cassava-Starch Coordinator (2006). PSI Cassava Project and Cassava Industry in Ghana. Unpublished Seminar Paper. Date and place of presentation not known.

(2006). President's Special Initiative (PSI). Unpublished Seminar Paper. Date and place of presentation not known.

Schubert, R. (1994). Poverty in Developing Countries: Its Definition, Extent and Implications. In Economics, Volume 49/50, pp 17-40. 
Ghana Journal of Development Studies, Volume 7, Number $2 \mid 2010$

Tonah, S. (2006). "The Presidential Special Initiative on Cassava: A Bane or Blessing to Ghana's Smallholder Farmers." Ghana Journal of Development Studies, Volume 3, No.1: 67-84. 